\title{
Pengaruh Pelatihan dan Pengembangan Serta Prestasi Kerja Terhadap Pengembangan Karir Pegawai Pada Dinas Koperasi Usaha Mikro Kecil Menengah Banjarmasin.
}

\author{
Wida Gerhana
}

\begin{abstract}
The Effects of Training and Development and Work Achievement on Employees' Career Development at the Department of Cooperatives, Micro, Small and Medium Enterprises in Banjarmasin.

The purpose of this study is to investigate employees' opinions on the effect of training and development and work achievement on employees' career development.

The populations in this study were 30 employees. The census method was used with the quantitative descriptive and explanatory research as its type of the study. Explaining the relationship of the effect of training and development and work achievement on employees' career development was used the multiple regression analysis. In order to test the hypothesis simultaneously, F-test has been used, while t-test has been used to test the hypothesis partially. The result showed that simultaneously and partially, the implementation of training and development and work achievement had a significant positive effect on employees' career development at the Dinas Koperasi Usaha Mikro Kecil Menengah in Banjarmasin. Both variables contributed $50.6 \%$, work achievement gave a greater influence than the training and development on employees' career development, even though the training and development also contributed in giving an influence.
\end{abstract}

Keywords : training and development, work achievement, career development

\section{ABSTRAK}

Telah dilakukan penelitian tentang Pengaruh Pelatihan dan Pengembangan Serta Prestasi Kerja terhadap Karier Pegawai Pada Dinas Koperasi Usaha Mikro Kecil Menengah Banjarmasin.

Tujuan penelitian ini adalah ingin mengetahui pendapat para pegawai tentang pengaruh pelatihan dan pengembangan serta prestasi kerja terhadap pengembangan karier pegawai.

Populasi penelitian berjumlah 30 orang yaitu seluruh pegawai,Metode yang digunakan adalah sensus dengan jenis penelitian adalah deskriptif kwntitatif dan sifat penelitian adalah penjelasan( explanatory).Untuk menjelaskan hubungan Pengaruh Pelatihan dan Pengembangan serta Pretasi kerja terhadap Karier pegawai menguunakan analisa regresi berganda.Untuk pengujian hipotesis penelitian secara serempak dilakukan uji $\mathrm{F}$ dan untuk pengujian hipotesis penelitian secara parsial digunakan uji t.Hasil penelitian menunjukkan bahwa secara serempak maupun parsial pelaksanaan pelatihan dan pengembangan serta pretasi kerja pegawai berpengaruh signifikan positif terhadap peningkatan karir pegawai pada Dinas Koperasi Usaha Mikro Kecil Menengah Banjarmasin.Dengan Kontribusi kedua Variabel sebesar 50,6 \%, Prestasi Kerja memberi pengaruh lebih besar daripada Pelatihan dan Pengembangan terhadap Karir Pegawai,meskipun Pelatihan dan Pengembangan turut berpengaruh.

Kata kunci : Pelatihan dan Pengembangan

Prestasi Kerja

Pengembangan Karir 


\section{I.PENDAHULUAN}

Organisasi yang baik tumbuh dan berkembang akan menitik beratkan pada Sumber Daya Manusia (Human Resources) guna menjalankan fungsinya dengan optimal, khususnya menghadapi dinamika perubahan lingkungan yang terjadi.Dengan demikian kemampuan tehnis, teoritis, konseptual, moral dari para pelaku organisasi disemua tingkat pekerjaan amat dibutuhkan.Selain itu pula kedudukan SDM pada posisi yang paling tinggi berguna untuk mendorong organisasi / lembaga menampilkan norma perilaku, nilai dan keyakinan sebagai sarana penting dalam peningkatan Kinerjanya.

Didalam kegiatan sehari-hari SDM melakukan pelayanan termasuk membuat Administrasi, bagaimana SDM dapat berkembang dan bertumbuh dalam iklim yang efektif dan efisien, untuk kegiatan pelayanan multi aspek pihak pimpinan kantor memiliki program Kerja Pelatihan dan Pengembangan.

Pelatihan dan Pengembangan yang sudah diberikan kepada pegawai seperti Diklat Komputer, Kesamaptaan, Dasar-dasar pemasyarakatan, Diklat Penjenjangan dan mengikuti perkuliahan, dengan adanya pelatihan dan pengembangan tersebut pimpinan berharap agar penyelesaian pekerjaan dan pelayanan dapat lebih meningkat.

Program pimpinan mengadakan pelatihan dan pengembangan banyak yang meng abaikan kesempatan berlatih tersebut, karena pegawai tidak melihat ada manfaat segera terhadap penilaian Prestasi dan penghasilan mereka.

Bagian SDM tidak memiliki suatu cara yang cukup kuat untuk memotivasi pegawai, karena mereka sendiri tidak melihat bahwa pengorbanan yang diberikan pegawai dalam mengikuti pelatihan dapat menghasilkan kompensasi maupun jenjang karir yang pasti.
Bagaimanakah persepsi pegawai Pada Dinas Koperasi Usaha Mikro Kecil

Menengah Banjarmasin tentang kaitan antara pelatihan dan pengembangan yang pernah diikuti serta prestasi kerja dan pengaruhnya dengan proses pengembangan karir yang ada disana, untuk menjawabnya penulis tertarik untuk melaksanakan penelitian.

Pelatihan dan pengembangan adalah dua dimensi upaya optimalisasi SDM yang memiliki orientasi tujuan yang berbeda, Pelatihan terarah pada peningkatan kemampuan dan keahlian SDM organisasi yang berkaitan dengan jabatan atau fungsi yang menjadi tanggung jawab individu yang bersangkutan saat ini (Current job oriented ),

Mangkuprawira

menyatakan Pelatihan bagi karyawan merupakan sebuah proses mengajarkan pengetahuan dan keahlian tertentu serta sikap agar karyawan semakin baik sesuai dengan standart.

Menurut Sulistyani \& Rosidah (2003) pelatihan adalah proses sistematik pengubahan perilaku para pegawai dalam suatu arah guna meningkatkan tujuan organisasi, Pelatihan dan Pengembangan penting karena keduanya merupakan cara untuk mempertahankan, menjaga, memelihara dan meningkatkan keahlian para pegawai.Sedangkan menurut Gomes ( 2003) Pelatihan adalah setiap usaha untuk memperbaiki performance pekerja pada suatu pekerjaan tertentu yang sedang menjadi tanggung jawabnya.

Istilah pelatihan sering disamakan dengan istilah Pengembangan. Pengembangan (development) menunjuk kepada kesempatan - kesempatan belajar yang di didesain guna membantu pengembangan para pekerja.

Wursanto (2009) menyatakan bahwa prestasi kerja adalah hasil kerja yang dicapai oleh seorang pegawai negeri sipil dalam melaksanakan tugas yang dibebankan kepadanya.Pada umumnya prestasi kerja seorang pegawai negeri sipil 
dipengaruhi oleh kecakapan, keterampilan, pengalaman dan kesungguhan pegawai negeri sipil yang bersangkutan.

Hasibuan ( 2004), mengemukakan bahwa Pengembangan Karir dalah suatu usaha untuk meningkatkan kemampuan teknis, teoritis, konseptual dan moral karyawan sesuai dengan kebutuhan pekerjaan jabatan melalui pendidikan dan latihan.

Moorehead \& Griffin (2000) menyatakan bahwa karir adalah suatu perjalanan yang ditanggapi didalam sikap dan perilaku terkait dengan pengalaman kerja dan kegiatan - kegiatan seseorang di sepanjang hidupnya, karier adalah suatu seri jangka panjang dalam hal tugas- tugas dan pengalaman kerja.

Sutarto (1999) menekankan bahwa karyawan mengharapkan pertumbuhan dan peluang karir.Menyediakan peluang demikian akan meningkatkan prestasi karyawan sebagai asset.Karenanya para pengambil keputusan strategi di organisasi mencantumkan sasaran pengembangan karyawan dalam rencana jangka panjang.

\section{II.TINJAUAN PUSTAKA}

\subsection{Pelatihan dan Pengembangan}

Simamora (2004: 273) Pelatihan dan pengembangan adalah dua istilah yang kadang-kadang digunakan secara bersamasama maupun secara bergantian.Pelatihan (training) mengandung maksud untuk menambah dan meningkatkan pengetahuan/keterampilan serta merubah sikap/perilaku karyawan ke arah yang produktif. Pengembangan (development) dapat diasosiasikan dengan kebutuhan masa depan karyawan dan organisasi perusahaan. Pelatihan dan pengembangan mempunyai

manfaat pada karier jangka panjang karyawan, untuk menghadapi tanggung jawab yang lebih besar di masa yang akan datang.Simamora (2004: 273-274) mengatakan Pelatihan dan pengembangan ditujukan untuk mempertahankan dan meningkatkan prestasi kerja para
karyawan.Pelatihan ditujukan untuk meningkatkan prestasi kerja saat ini, sedangkan pengembangan ditujukan untuk meningkatkan prestasi kerja saat ini dan masa yang akan datang. Pelatihan diarahkan untuk membantu karyawan melaksanakan pekerjaan saat ini secara lebi baik.Pengembangan mewakili investasi pengembangan yang berorientasi masa depan pada diri karyawan.

Baik karyawan manajerial maupun non manajerial barangkali akan lebih banyak menerima pelatihan yang bersifat teknis dibandingkan dengan manajer yang lebih banyak menerima pengembangan dalam bentuk keterampilan konseptual atau analitis dan keterampilan hubungan manusiawi untuk memperdalam wawasan mereka guna membawa rekrutmen pada tujuan yang strategis dan spesifik.

Selanjutnya pengertian pelatihan secara sederhana didefinisikan oleh Pramudyo (2007 : 16) sebagai: "Proses pembelajaran yang dirancang untuk mengubahkinerjaorangdalammelakukanpe kerjaannya"

Dessler (2006: 280) bahwa : "Pelatihan merupakan proses mengajar keterampilan yang dibutuhkan karyawan untuk melakukan pekerjaannya. Mangkuprawira (2002: 135) menjelaskan bahwa: "Pelatihan adalah sebuah proses mengajarkan pengetahuan dan keahlian tertentu serta sikap agar karyawan semakin terampil dan mampu melaksanakan tanggung jawab dengan semakin baik sesuai dengan standar".

Pengembangan (development) cenderung lebih bersifat formal,menyangkut antisipasi kemampuan dan keahlian individu yang harus di persiapkan bagi kepentingan jabatan yang akan datang.Sasaran program pengembangan yaitu peningkatan kemampuan individu untuk mengantisipasi perubahan yang mungkin terjadi tanpa direncanakan (unplanned change) atau perubahan yang direncanakan (planed change)

Alwi,2001). 
Mathis R. Jackson (2002) pengembangan adalah pertumbuhan kemampuan yang terjadi jauh melampaui apa-apa yang dituntut dalam suatu pekerjaan.Halinimewakili usahausaha untuk meningkatkan kemampuan karyawan untuk menanganiberbagai jenis penugasan. Pengembangan ini dilakukan untuk menambah pengetahuan dan keahlian ataupun keterampilan mereka sehingga dapat menunjang adanya kesempatan dalam promosi karyawan. Setiap pimpinan/atasan perlu melakukan pengembangan sumber daya manusia, sebab melalui pengembangan ini perusahaan akan mempunyai tenaga kerja yang terampil dan cakap, dengan demikian tujuan perusahaan dapat terealisasikan dengan baik.Menurut Rivai (2000) pengembangan adalah proses peningkatan kemampuan kerja individual yang tercapai dalam rangka mencapai karir yang diinginkan.Menurut Hasibuan (2007) Perkembangan adalah suatu usaha untuk meningkatkankemampuan teknis, teoritis, konseptual, dan moral karyawan sesuai dengan kebutuhan pekerjaan/ jabatan melalui pendidikan dan pelatihan. Menurut Mangkunegara (2000) pengembangan merupakan suatu proses pendidikan jangka panjangyangmempergunakan prosedur sistematis dan terorganisasi dimana karyawan managerial mempengaruhi pengetahuan konseptual dan teoritis guna mencapai tujuan yang umum.

\subsection{Prestasi Kerja}

Prestasi kerja adalah hasil kerja yang dicapai oleh seseorang pegawai dalam melaksanakan tugas yang dibebankan kepadanya.

\subsection{Pengembangan Karir}

Pengembangan karir pegawai biasa dilakukan dua jalur yaitu melalui pelatihan dan pendidikan ( Diklat ) dan melalui non diklat ( Weightman, 2002).

Menurut Alwi ( 2001) bahwa karir secara tradisional dibangun melalui tangga yang bersifat linear sehingga kriteria kemampuan, keahlian dan pengetahuan yang dimiliki seorang karyawan untuk menduduki jenjang jabatan yang lebih tinggi berbeda dengan konsep karir yang lebih maju.Dilihat dari sudut kepentingan organisasi Kaflan dan Norton ( 2004) dalam strategy Maps mengungkapkan bahwa manajemen yang strategis perlu memulai perjalanan strategis dari titik pelatihan dan pengembangan SDM.Pada tahap kedua organisasi perlu menumbuhkan dan merawat personel seoptimal mungkin.Tujuan pemeliharaan melalui pelatihan dan pengembangan.

\section{III.METODE PENELITIAN}

\subsection{Metode Penelitian}

Metode penelitian yang digunakan adalah sensus.Jenis penelitian adalah deskriftif kwantitatif dan sifat penelitian adalah penjelasan ( explanatory) yaitu untuk menjelaskan tentang Pengaruh Pelatihan dan Pengembangan serta Prestasi Kerja terhadap Pengembangan Karir Pegawai pada Dinas Koperasi Usaha Mikro Kecil Menengah Banjarmasin

\subsection{Populasi dan Sample}

Subyek dalam penelitian ini adalah seluruh pegawai sebanyak orang. Menurut Arikunto ( 2002) jika jumlah subyeknya kurang dari 100, maka lebih baik semua subyeknya diteliti, sehingga penelitiannya merupakan penelitian populasi, karena sampelnya meliputi semua subyek yang terdapat didalam populasi

Menurut Sugiyono ( 2008) semua anggota populasi dijadikan sample disebut sampling jenuh atau istilah lainnya adalah Sensus.

\subsection{Cara Pengumpulan Data}

Pengumpulan Data dilakukan dengan memakai cara sebagai berikut :

1. Menyebarkan daftar pertanyaan ( kuesioner) dan memberikan kepada pegawai Dinas Koperasi Usaha Mikro Kecil Menengah Banjarmasin. 
2.Melakukan wawancara terhadap responden untuk melengkapi data yang diperoleh melalui kuesioner.

3. Melakukan studi dokumentasi dengan mencari data pada dokumn dokumen yang ada pada Dinas Koperasi Usaha Mikro Kecil Menengah.

\subsection{Identifikasi Variabel}

Berdasarkan perumusan masalah, kerangka berfikir dan Hipothesis yang diajukan maka variabel-variabel dalam penelitian ini adalah sebagai berikut :

1.Variabel Bebas atau Independent Variabel ( $\mathrm{X}$ ) yaitu Pelatihan dan Pengembangan ( X1) dan Prestasi Kerja ( X2 ).

2.Variabel terikat atau Dependent Variabel Yaitu Pengembangan Karier ( Y )

\subsection{Definisi Operasional Variabel}

Definisi operasional adalah batasan- batasan yang ditetapkan dari variabel-variabel yang dipakai sebagai hal yang digunakan sebagai alat analisis pada penelitian .Butir butir tersebut secara jelas dapat dibaca disetiap bentuk pertanyaan dan pernyataan yang ditulis pada setiap item kuesioner.Secara singkat diuraikan sebagai berikut :

1. Pelatihan dan pengembangan dimaksud adalah jenis -jenis pelatihan kerja,pada pihak pegawai masing-masing yang pernah diberikan di kantor pada Dinas Koperasi Usaha Mikro Kecil Menengahterkait dengan tugas yang di emban.

2. Prestasi Kerja

Adalah hasil kerja yang dicapai oleh seorang pegawai dalam melaksanakan tugas yang dibebankan kepadanya.

3. Pengembangan Karier Pegawai Mengandung makna bagaimana pegawai merasakan pencapaian kariryang dialami selama bekerja pada Dinas Koperasi Usaha Mikro Kecil Menengah.

\section{6 .Skala Ukur}

Pengukuran nilsi data dibuat berdasrkan model pengukuran Skala Likert dengan 5 kemungkinan persetujuan oleh responden terhadap pertanyaan pada item kuesioner Item kuesioner sendiri telah di struktur mengikuti kebutuhan data untuk uji Hipotesis dan analisis sesuai dengan tujuan penelitian.

Tabel 3.1 Matrik Variabel -variabel dalam definisi Operasional

\begin{tabular}{|c|c|c|c|}
\hline Variabel & $\begin{array}{l}\text { Definisi } \\
\text { operasional }\end{array}$ & Indikator & $\begin{array}{l}\text { Pengukur } \\
\text { an }\end{array}$ \\
\hline $\begin{array}{l}\text { Pelatihan } \\
\text { dan } \\
\text { pengemban } \\
\text { gan }\end{array}$ & $\begin{array}{l}\text { Meningkatkan } \\
\text { ketrampilan } \\
\text { kerja dalam } \\
\text { melaksanakan } \\
\text { pekrjaan khas } \\
\text { dan } \\
\text { pengembangan } \\
\text { untuk } \\
\text { meningkatkan } \\
\text { pengetahuan } \\
\text { umum yang } \\
\text { terkait } \\
\text { pemahaman } \\
\text { atas } \\
\text { keseluruhan } \\
\text { lingkungan. }\end{array}$ & $\begin{array}{l}\text {-Analisis } \\
\text { organisasio } \\
\text { nal } \\
\text {-Analisis } \\
\text { operasional } \\
\text {-Analisis } \\
\text { Individu } \\
\text {-Fasilitas } \\
\text { - } \\
\text { Pelaksanaan } \\
\text { program } \\
\text {-Reaksi } \\
\text {-Sikap } \\
\text {-Hasil }\end{array}$ & $\begin{array}{l}\text { Skala } \\
\text { Likert }\end{array}$ \\
\hline $\begin{array}{l}\text { Prestasi } \\
\text { Kerja }\end{array}$ & $\begin{array}{lr}\text { Hasil Kerja } & \text { Kang dicapai } \\
\text { yang } \\
\text { oleh seorang } \\
\text { PNS dalam } \\
\text { melaksanakan } \\
\text { tugas yang } \\
\text { dibebankan } \\
\text { kepadanya. }\end{array}$ & $\begin{array}{l}\text {-Kuantitas } \\
\text {-Kualitas } \\
\text {-Kerjasama } \\
\text {-Penilaian } \\
\text { Prestasi } \\
\text {-Disiplin }\end{array}$ & $\begin{array}{l}\text { Skala } \\
\text { likert }\end{array}$ \\
\hline $\begin{array}{l}\text { Pengemban } \\
\text { gan karir }\end{array}$ & $\begin{array}{l}\text { Suatu usaha } \\
\text { untuk } \\
\text { meningkatkan } \\
\text { kemampuan } \\
\text { teknis, } \\
\text { teoritis,konsep } \\
\text { tual dan moral } \\
\text { karyawan } \\
\text { sesuai dengan } \\
\text { kebutuhan } \\
\text { pekerjaan/jabat } \\
\text { an melalui } \\
\text { pendidikan an } \\
\text { latihan. }\end{array}$ & $\begin{array}{l}\text { Organisasio } \\
\text { nal } \\
\text { Individual } \\
\text { Prestasi } \\
\text { kerja } \\
\text { Lowongan } \\
\text { jabatan } \\
\text { Kesetiaan } \\
\text { organisasi } \\
\text { Tingkat } \\
\text { pendidikan }\end{array}$ & $\begin{array}{l}\text { Skala } \\
\text { Likert }\end{array}$ \\
\hline
\end{tabular}




\subsection{Tekhnik Analisa Data}

Penelitian ini bertujuan menguji dan menganalisis antar variabel dengan menggunakan Analisis Regresi berganda, sekaligus memeriksa Validitas dan Reliabilitas instrumen penelitian secara keseluruhan, serta diadakanuji klasik (uji multikolinieritas, uji Hetereskedastisitas dan uji Autokorelasi) antara variabel independent) untuk mengetahui ketepatan model regresi dimaksud.Oleh karena itu digunakan teknik analisis Regresi berganda menggunakan Sofware SPSS 19.

\subsection{Model Analisis Data}

Metode Analisis data yang digunakan untuk menjawab hipotesis adalah Regresi Berganda dengan Formula sebagai berikut :

$$
\mathrm{Y}=\mathrm{a}+\mathrm{b} 1 \mathrm{X} 1+\mathrm{b} 2 \mathrm{X} 2+\mathrm{e}
$$

Dimana.. $\mathrm{Y}=$ Pengembangan Karier

$$
\mathrm{X} 1 \text { =Pengembangan dan }
$$

Pelatihan

X2 $=$ Prestasi Kerja Pegawai

$\mathrm{a}=$ Konstanta

$\mathrm{b} 1, \mathrm{~b} 2=$ Koefisien Regresi variabel independent

$\mathrm{e}=$ Error Term

Pengujian statistik dengan model regresi berganda, digunakan langkah langkah uji signifikansi yaitu :

1.Pengujian Hipotesis untuk uji serempak ( uji F ) untuk melihat signifikasi secara simultan variabel terikat terhadap variabel bebas

$\mathrm{HO} ; \mathrm{b} 1, \mathrm{~b} 2=0$

( Pelatihan dan Pengembangan serta

Prestasi Kerja pegawai serempak

( simultan) tidak berpengaruh

terhadap pengembagan karier

pegawaidi Dinas Koperasi Usaha

Mikro Kecil Menengah.

Ha ; b1,b2 $\neq 0$ (Pelatihan dan

Pengembangan serta Prestasi Kerja pegawai serempak ( simultan)

berpengaruh terhadap pengembagan karier pegawai di Dinas Koperasi Usaha Mikro Kecil Menengah.

Untuk menguji apakah Hipotesis yang diajukan diterima atau ditolak digunakan statistik F ( $\mathrm{F}$ test), Jika F hitung $\leq$ Ftabel , maka H0 diterima dan Ha ditolak.

Sebaliknya jika $F$ hitung $\geq F$ tabel, maka $\mathrm{H} 0$ ditolak dan $\mathrm{Ha}$ diterima.

Hal ini berarti bahwa variabel bebasnya secara serempak mempunyai pengaruh yang signifikan terhadap variabel terikatnya.

2. Uji Parsial ( uji t) untuk melihat pengaruh secara parsial masingmasing variabel bebasnya terhadap variabel terikat.Tingkat kepercayaan adalah $95 \%$ dan level pengujian yang digunakan $\alpha=5 \%$. Apabila nilai $\mathrm{t}$ hit $\geq \mathrm{t}$ tab maka $\mathrm{H} 0$ diterima dan $\mathrm{Ha}$ ditolak, hal ini berarti bahwa variabel-variabel bebasnya secara serempak tidak mempunyai pengaruh yang signifikan terhadap variabel terikatnya.

Sebaliknya apabila $\mathrm{t}$ hit $\leq \mathrm{t}$ tab maka Ho ditolak dan Ha diterima hal ini berarti bahwa variabel bebasnya secara parsial mempunyai pengaruh yang signifikan terhadap variabel terikatnya.

\section{IV.HASIL PENELITIAN DAN PEMBAHASAN}

\subsection{Keadaan Pegawai Negeri Sipil di Dinas Koperasi Usaha Mikro Kecil Menengah. Jumlah Pegawai 30 orang sebagaimana tabel berikut.}


Tabel.1.4

Pegawai Menurut Golongan

\begin{tabular}{|c|c|c|}
\hline No & Golongan & Jumlah \\
\hline 1 & I & 1 \\
2 & II & 3 \\
3 & III & 22 \\
4 & IV & 4 \\
& & \\
\hline & Jumlah & 30 \\
\hline
\end{tabular}

Sumber : Bagian Kepegawaian

Tabel 1.4 diatas menunjukkan bahwa modus dari Golongan adalah Gol III

Tabel.2.4

Pegawai Menurut Tingkat Pendidikan

Sumber : Bagian Kepegawaian

\begin{tabular}{|c|c|c|}
\hline No & Tingkat Pendidikan & Jumlah \\
\hline 1 & SD & 0 \\
2 & SLTP & 0 \\
3 & SLTA & 1 \\
4 & SARMUD & 3 \\
5 & SARJANA (S1) & 25 \\
6 & SARJANA ( S2) & 1 \\
\hline & Jumlah & 30 \\
\hline
\end{tabular}

Tabel 2.4 diatas menunjukkan bahwa statistik distribusi pendidikan pegawai .Modus dari tingkat pendidikan adalah pada Strata 1( S1)

Tabel 3.4

Pegawai Menurut Jenis Kelamin

\begin{tabular}{|c|c|c|}
\hline No & Jenis Kelamin & Jumlah \\
\hline 1 & Pria & 25 \\
2 & Wanita & 5 \\
\hline & Jumlah & 30 \\
\hline
\end{tabular}

Sumber : Bagian Kepegawaian

Tabel 3.4 diatas menunjukkan bahwa jumlah pegawai didominasi oleh pegawai pria.Proporsi tersebut dapat diterima karena tugas banyak terjun ke lapangan
Tabel 4.4

Pegawai menurut Usia

\begin{tabular}{|c|l|l|}
\hline No & Usia (thn) & Jumlah \\
\hline 1 & $20-29$ & 4 \\
2 & $30-39$ & 18 \\
3 & $40-49$ & 6 \\
4 & $>50$ & 2 \\
\hline & \multicolumn{2}{|c|}{30} \\
\hline
\end{tabular}

Sumber : Bagian Kepegawaian

Pada tabel 4.4 diatas menunjukkan bahwa modus dari umur pegawai adalah pada rentang $30-39$ tahun yaitu sebanyak 18 orang, berdasarkan komposisi tersebut diharapkan cukup tepat untuk memberikan jawaban yang sesuai dengan pertanyaan dalam angket penelitian

\subsection{Uji Validitas dan Realibilitas}

\section{a.Uji Validitas}

Pengujian validitas dalam penelitian ini menggunakan analisa item, yaitu dengan mengkorelasikan Skor setiap item dengan skor total sebagai jumlah dari skor item .Teknik Korelasi yg digunakan adalah teknik korelasi product moment pearson pada tingkat signifikansi $95 \% \quad(\alpha=0,05)$.Uji validitas digunakan untuk mengetahui kesahihan instrumen yang digunakan,untuk menentukan sebuah item valid atau tidak, perlu dibandingkan antara nilai koeefisien korelasi ( $r$ ) hasil perhitungan dengan nilai koeffisien korelasi dalam tabel. Pada angka 5\% derajat bebas ( $\mathrm{N}-2$ ), nilai $\mathrm{r}$ dalam tabel sebesar 0,361. Apabila $r$ hasil perhitungan lebih besar dari $r$ tabel makasignifikansi yang berarti item tersebut valid dan dapat digunakan untuk mengukur variabel yang akan diukur.Instrumen penelitian ini di cobakan pada semua responden, setelah kuesioner disebarkan terkumpul jawaban responden berupa skor dapat dilihat pada tabel. 
Tabel 4.5

Hasil Pengujian validitas instrumen

\begin{tabular}{|c|c|c|c|c|}
\hline No. & \multicolumn{1}{|c|}{ Variabel } & $\begin{array}{l}\text { Koeffisien } \\
\text { Korelasi } \\
(\mathrm{r})\end{array}$ & $\mathrm{r}$ & Ket. \\
\hline 1 & $\begin{array}{l}\text { Pengembangan } \\
\text { dan Pelatihan } \\
\text { ( X1) }\end{array}$ & 0,727 & 0,361 & Valid \\
\hline 2 & $\begin{array}{l}\text { Prestasi Kerja } \\
\text { (X2) }\end{array}$ & 0,850 & 0,361 & Valid \\
\hline 3 & $\begin{array}{l}\text { Pengembangan } \\
\text { Karier ( Y ) }\end{array}$ & 0,692 & 0,361 & Valid \\
\hline
\end{tabular}

Sumber : Data Primer diolah

\section{b. Uji Reliabilitas}

Pengujian Reliabilitas dalam penelitian ini menggunakan metode alpha cronbach, bertujuan untuk menguji konsistensi instrumen yang digunakan.

Hasil pengujian disajikan pada tabel berikut.

Tabel 4.6

Hasil Pengujian Reliabilitas instrumen

\begin{tabular}{|c|c|c|}
\hline Variabel & $\begin{array}{c}\text { Nilai } \\
\text { Alpha }\end{array}$ & Keterangan \\
\hline X1 & 0,8205 & Reliabel \\
X2 & 0,8427 & Reliabel \\
Y & 0,7450 & Reliabel \\
\hline
\end{tabular}

Sumber : Data Primer diolah

Menurut azwar ( 2010) bahwa koeffisien Reliabilitas berkisar antara 0 sampai dengan 1, semakin mendekati 1 menunjukkan instrumen tersebut semakin Reliabel.Pada tabel perhitungan diatas menunjukkan bahwa nilai alpha masing masing variable memiliki nilai lebih besar dari 0 ( mendekati 1) sehingga instrumen dinyatakan Reliabel.

\section{3.ANALISIS DISKRIPSI \\ VARIABEL}

Dari sebaran kuesioner, dilihat dari jawaban responden atas pertanyaan yang terkait dengan Variabel Pelatihan dan Pengembangan tersaji pada tabel berikut :

Tabel 4.7

Jawaban Responden

\begin{tabular}{|c|c|c|c|c|c|c|}
\hline \multirow[t]{2}{*}{ No : $\quad$ Pertanyaan } & \multicolumn{5}{|c|}{ Persen Pilihan Jawaban } & \multirow[t]{2}{*}{ Total } \\
\hline & STS & TS & $\mathrm{N}$ & $\mathrm{S}$ & SS & \\
\hline $\begin{array}{l}\text { 1.Program peltihan sesuai } \\
\text { dng tujuan organisasi }\end{array}$ & 0,0 & 0,0 & 25 & 67.7 & 7,3 & 100 \\
\hline $\begin{array}{l}\text { 2.Program Pelatihan sesuai dng } \\
\text { peningkatan karir }\end{array}$ & 0,0 & 0,0 & 16 & 60,9 & 23,1 & 100 \\
\hline \begin{tabular}{|l} 
3.Program Pelatihan utk \\
$\begin{array}{l}\text { adaptasi } \\
\text { organisasi }\end{array}$ \\
iklim
\end{tabular} & 0,0 & 3,6 & 27 & 63,5 & 5,9 & 100 \\
\hline $\begin{array}{l}\text { 4.ProgramPelatihan membantu } \\
\text { peningkatan keahlian }\end{array}$ & 0,0 & 0,0 & 10,7 & 62,5 & 26,8 & 100 \\
\hline \begin{tabular}{|lr} 
5.Program & Pelatihan \\
membantu & peningkatan \\
keterampilan & \\
\end{tabular} & 0,0 & 0,0 & 53,3 & 47 & 0,0 & 100 \\
\hline $\begin{array}{l}\text { 6.Program Pelatihan membantu } \\
\text { peningkatan pengetahuan }\end{array}$ & 0,0 & 0,0 & 26,5 & 73,5 & 0,0 & 100 \\
\hline $\begin{array}{l}\text { 7.Program Pelatihan membantu } \\
\text { peningkatan karir }\end{array}$ & 0,0 & 0,0 & 2,8 & 85,0 & 12,2 & 100 \\
\hline $\begin{array}{l}\text { 8.Fasilitas program pelatihan } \\
\text { telah tersedia }\end{array}$ & 0,0 & 27,3 & 64,3 & 8,4 & 0,0 & 100 \\
\hline $\begin{array}{l}\text { 9.Program Pelatihan } \\
\text { dengan tujuan program }\end{array}$ & 0,0 & 0,0 & 3,1 & 79,6 & 17,3 & 100 \\
\hline $\begin{array}{l}\text { 10.Program Pelatihan sesuai } \\
\text { dengan program organisasi }\end{array}$ & 0,0 & 0,0 & 8,9 & 63,7 & 27,4 & 100 \\
\hline $\begin{array}{l}\text { 11. Program Pelatihan memberi } \\
\text { dampak positif }\end{array}$ & 0,0 & 19,10 & 68,9 & 12 & 0,0 & 100 \\
\hline $\begin{array}{l}\text { 12.ProgramPelatihan } \\
\text { membantu } \\
\text { menyelesaikan } \\
\text { pekerjaan }\end{array}$ & 0,0 & 0,0 & 2,6 & 73,6 & 23,8 & 100 \\
\hline $\begin{array}{l}\text { 13.Program Pelatihan mampu } \\
\text { memberi perubahan sikap }\end{array}$ & 0,0 & 0,0 & 4,2 & 68,7 & 27,1 & 100 \\
\hline Rata - Rata & 0,0 & 3,9 & 24,1 & 58,9 & 13,1 & 100 \\
\hline
\end{tabular}

Sumber: Data diolah dari hasil jawaban Responden 
Pada Tabel 4.7 menunjukkan bahwa mayoritas responden setuju bahwa program

Pelatihan dan Pengembangan yang telah dilaksanakan sesuai dengan tujuan organisasi,peningkatan karir pegawai, sebagai cara untuk mengadaptasi perubahan iklim organisasi dan peningkatan keahlian serta pengetahuan.Dengan adanya program pelatihan dan pengembangan cukup mampu membantu para pegawai dalam menyelesaikan pekerjaan mereka dan memberikan perubahan sikap para pegawai kearah yang lebih baik dalam bekerja.Berdasarkan penilaian para responden tersebut maka dapat memberikan gambaran bahwa program pelatihan dan pengembangan pegawai mendapat apresiasi yang positif dari para pegawai, dari gambaran tersebut dapat kita asumsikan bahwa dengan pelaksanaan pendidikan dan pengembangan yang konsisten dan terpola secara cermat diyakini dapat mempengaruhi peningkatan prestasi para pegawai, yang akhirnya terhadap peningkatan karir pagawai secara umum.

Prestasi kerja bagi pegawai merupakan salah satu tolak ukur untuk menentukan apakah seorang pegawai layak atau tidak mendapatkan promosi untuk pengembangan karir kedepan. Penilaian para pegawai terhadap pertanyaan pertanyaan yang terkait dengan variabel prestasi kerja dapat terlihat pada table 4.8 berikut :Tabel 4.8

Jawaban Responden Terhadap Pertanyaan Variabel Prestasi kerja

\begin{tabular}{|c|c|c|c|c|c|c|}
\hline \multirow{2}{*}{$\begin{array}{l}\text { No : } \\
\text { Pertanyaan }\end{array}$} & \multicolumn{5}{|c|}{ Persen Pilihan Jawaban } & \multirow{2}{*}{$\begin{array}{c}\text { Tot } \\
\text { al }\end{array}$} \\
\hline & STS & TS & $\mathrm{N}$ & $\mathrm{S}$ & SS & \\
\hline $\begin{array}{l}\text { 1.Oganisasi } \\
\text { memberi } \\
\text { tugas pd } \\
\text { stiap seksi }\end{array}$ & 0,0 & 0,0 & 14,5 & 70,2 & 15,3 & 100 \\
\hline $\begin{array}{l}\text { 2.Pekerjaan } \\
\text { dari } \\
\text { rganisasi } \\
\text { sesuai } \\
\text { dng } \\
\text { kemampuan }\end{array}$ & 0,0 & 0,0 & 20,5 & 73,1 & 6,4 & 100 \\
\hline
\end{tabular}

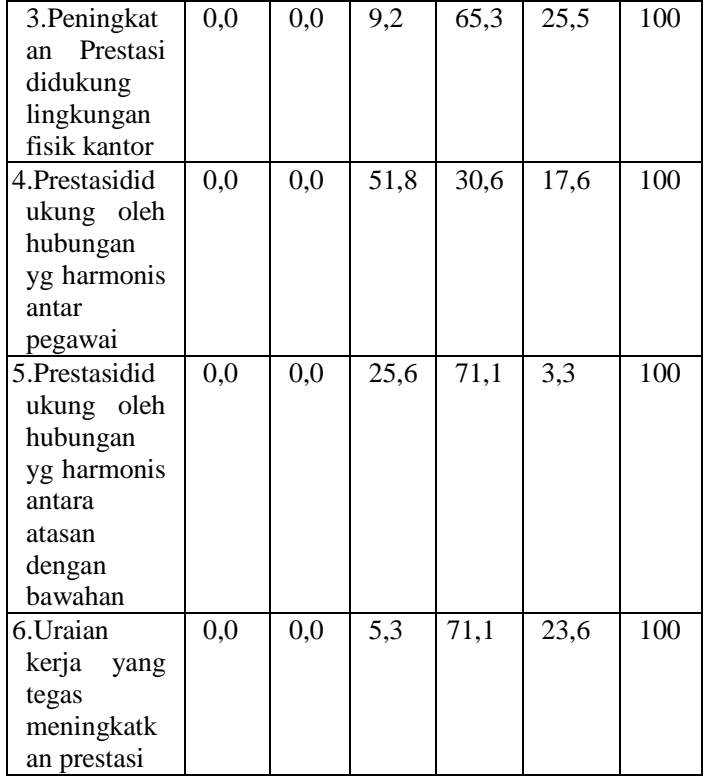

Sumber: Data diolah dari hasil jawaban Responden

Pada table 4.8 secara umum pegawai setuju tugas -tugas dari organisasi telah didelegasikan pada tiap-tiap seksi yang berkompeten atas tugas tersebut, pekerjaan yang diberikan telah sesuai dengan kemampuan yang telah dimiliki oleh masing -masing pegawai, lingkungan phisik kerja yang baik,hubungan kerja yang harmonis antar sesama rekan kerja dan antar sesame rekan kerja dan antar atasan dengan bawahan akan mempengaruhi peningkatan prestasi kerja, setiap pegawai ber hak mendapatkan pelatihan dan pengembangan untuk peningkatan kemampuan.

Juga responden berpendapat dengan tugas dan pekerjaan para pegawai telah dilaksanakan secara baik sesuai dengan tuntutan organisasi.Para responden juga cukup sependapat hubungan yang harmonis antar sesame pegawai cukup mampu menjadi pendukung pencapaian prestasi para pegawai, juga keteladanan pimpinan dalam disiplin waktu dan penilaian hasil kerja yang objektif dari pimpinan juga turut mendukung pencapaian prestasi kerja yang optimal dari setiap pegawai. 
Tabel 4.9

Jawaban Responden Terhadap Pertanyaan Variabel Pengembangan Karir

\begin{tabular}{|c|c|c|c|c|c|c|}
\hline \multirow{2}{*}{$\begin{array}{l}\text { No } \\
\text { Pertanyaan }\end{array}$} & \multicolumn{5}{|c|}{ Persen Pilihan Jawaban } & \multirow{2}{*}{$\begin{array}{l}\text { To } \\
\text { tal }\end{array}$} \\
\hline & STS & TS & $\mathrm{N}$ & $\mathrm{S}$ & SS & \\
\hline $\begin{array}{l}\text { 1.Organisasi } \\
\text { memberikan } \\
\text { kesempatan yg } \\
\text { sama untuk } \\
\text { peningkatan } \\
\text { jabatan }\end{array}$ & 0,0 & 0,0 & 22,9 & 69,4 & 7,7 & 100 \\
\hline $\begin{array}{l}\text { 2.Jalur Promosi } \\
\text { tidak selalu sesuai } \\
\text { dengan bidang } \\
\text { pekerjaan }\end{array}$ & 0,0 & 0,0 & 11,8 & 64,5 & 23,7 & 100 \\
\hline $\begin{array}{lr}\text { 3.Jabatan } & \text { telah } \\
\text { sesuai } & \text { dengan } \\
\text { pekerjaan pegawai }\end{array}$ & 0,0 & 22,4 & 20,4 & 55,3 & 1,9 & 100 \\
\hline $\begin{array}{lr}\text { 4.Jabatan } & \text { telah } \\
\text { sesuai } & \text { dengan } \\
\text { prestasi kerja } & \\
\end{array}$ & 0,0 & 0,0 & 10,5 & 61,8 & 27,6 & 100 \\
\hline $\begin{array}{lr}\text { 5.Jabatan } & \text { telah } \\
\text { sesuai } & \text { dengan } \\
\text { prestasi kerja yang } \\
\text { dicapai }\end{array}$ & 0,0 & 13,2 & 56,9 & 27,6 & 2,3 & 100 \\
\hline $\begin{array}{l}\text { 6.Pegawai } \\
\text { berprestasi perlu } \\
\text { mendapat peluang } \\
\text { karir yg lebih baik }\end{array}$ & 0,0 & 0,0 & 23,3 & 71,4 & 5,3 & 100 \\
\hline $\begin{array}{l}\text { 7.Tim kerja } \\
\text { dibentuk atas dasar } \\
\text { kedekatan } \\
\text { hubungan personal } \\
\text { dengan pimpinan }\end{array}$ & 0,0 & 0,0 & 2,6 & 82,5 & 14,9 & 100 \\
\hline $\begin{array}{l}\text { 8.Jabatan sesuai } \\
\text { dengan } \\
\text { kemampuan dan } \\
\text { latar belakang } \\
\text { pendidika }\end{array}$ & 0,0 & 26,9 & 64,8 & 5,3 & 3,0 & 100 \\
\hline $\begin{array}{l}\text { 9.Promosi lebih } \\
\text { ditentukan oleh } \\
\text { prestasi dibanding } \\
\text { masa kerj }\end{array}$ & 0,0 & 0,0 & 2,6 & 80,3 & 17,1 & 100 \\
\hline $\begin{array}{l}\text { 10.Kenaikan } \\
\text { jabatan dilakukan } \\
\text { jika ada formasi } \\
\text { jabatan yang } \\
\text { kosong }\end{array}$ & 0,0 & 0,0 & 9,2 & 60,5 & 30,3 & 100 \\
\hline $\begin{array}{l}\text { 11.Ada percepatan } \\
\text { kenaikan jabatan } \\
\text { bagi pegawai } \\
\text { dengan prestasi yg } \\
\text { cemerlang }\end{array}$ & 0,0 & 15,7 & 70,7 & 10,5 & 3,1 & 100 \\
\hline $\begin{array}{l}\text { 12.Prestasi } \\
\text { mempengaruhi } \\
\text { pengemb.karir } \\
\text { dalam organisasi. }\end{array}$ & 0,0 & 0,0 & 2,6 & 72,4 & 25,0 & 100 \\
\hline \begin{tabular}{lr}
\multicolumn{2}{l}{ 13.Perencanaan } \\
karir & dari \\
organisasi & telah \\
dipahami & oleh \\
pegawai & \\
\end{tabular} & 0,0 & 0,0 & 3,9 & 70,4 & 25,7 & 100 \\
\hline
\end{tabular}

\begin{tabular}{|l|l|l|l|l|l|l|}
\hline $\begin{array}{l}\text { 14.Pelatihan dan } \\
\text { Pengembangan } \\
\text { dapat bermanfaat } \\
\text { untuk } \\
\text { pengemb.karier }\end{array}$ & 0,0 & 0,0 & 36,6 & 55,4 & 8,0 & 100 \\
\hline $\begin{array}{l}\text { 15.Senioritas } \\
\text { merupakan faktor } \\
\text { utama promosi } \\
\text { jabatan }\end{array}$ & 0.0 & 0,0 & 0,0 & 53,2 & $\begin{array}{l}46, \\
8\end{array}$ & 100 \\
\hline $\begin{array}{l}\text { 16.Jabatan telah } \\
\text { sesuai dengan } \\
\text { aturan yang } \\
\text { berlaku }\end{array}$ & 0,0 & 0,0 & 35,5 & 62,2 & 2,3 & 100 \\
\hline \multicolumn{2}{|l|}{ Rata-Rata } & & & & & \\
\hline
\end{tabular}

Tabel 4.9 menunjukkan bahwa mayoritas responden setuju jika organisasi tempat mereka bekerja telah memberikan kesempatan yang sama besar dalam hal pengembangan karir atau jabatan, promosi jabatan telah dilakukan sesuai dengan bidang pekerjaan, jabatan telah ditentukan sesuai dengan bidang pekerjaan yang seharusnya,jabatan telah sesuai dengan prestasi kerja yang dicapai pegawai, prestasi kerja yang baik layak menjadi penentu utama jenjang karir pegawai, hubungan baik menjadi pertimbangan untuk sebuah tim kerja dalam sebuah organisasi, promosi jabatan dilaksanakan karena ada formasi jabatan yang kososng disamping pretasi masa kerja juga dianggap pantas menjadi prioritas dalam promosi jabatan, mekanisme promosi jabatan telah dilaksanakan sesuai dengan aturan yang berlaku.Disisi lain para responden juga cukup sepakat bahwa jabatan yang merekan emban telah sesuai dengan prestasi dan latar belakang pendidikan yang telah mereka capai selama bekerja, selalu ada percepatan jenjang karir bagi pegawai dengan pretasi yang cemerlang dan penilaian prestasi kerja pegawai telah dilakukan secara objektif oleh pimpinan organisasi.

\section{4 .Pengujian Asumsi Klasik Regresi Linear Berganda.}

Untuk mengetahui apakah hasil estimasi regresi yang dilakukan betul-betul terbebas dari adanya gejala Multikolinearitas, gejala Autokorelasi dan 
gejala Heteroskedastisitas perlu dilakukan pengujian .

a. Multikolinearitas

Adanya Multikolinearitas dalam model regresi dapat diketahui dengan cara melihat nilai VIF ( Variance Inflation Faktor ) masing-masing variabel bebas.Nilai VIF lebih besar dari 5 menandakan derajat Multikolinearitas yang tinggi Hasil pengujian Multikolinearitas disajikan pada tabel.

Tabel 4.10

Hasil uji Multikolinearitas

\begin{tabular}{|c|c|c|}
\hline Variabel & Tolerence & VIF \\
\hline $\mathrm{X} 1$ & 0,876 & 1,142 \\
\hline $\mathrm{X} 2$ & 0,951 & 1,052 \\
\hline
\end{tabular}

Sumber : Data primer diolah menggunakan SPSS 19

Pada umumnya jika VIF lebih besar dari 10 maka variabel tersebut mempunyai persoalan Multikolinearitas dengan variabel lainnya, jika dilihat pada tabel diatas maka variabel bebas mempunyai VIF dibawah 10 yang berarti tidak terdapat multikolinearitas.

\section{b. Autokorelasi}

Menurut Wibowo dan Sugiyono ( 2013 ), nilai Durbin - Watson digunakan untuk menentukan uji autokorelasi dengan ketentuan apabila nilai Durbin -Watson dibawah 5 maka tidak terjadi autokorelasi.Sedangkan bukunya Nachrowi dan Usman ( 2011 ) kalau du < d > 4 - du dapat dikatakan dalam model tidak ada autokorelasi. Berdasarkan hasil pengolahan didapat statistik Durbin Watson sebesar 1,628. Dari tabel DurbinWatson $\alpha=5 \%, n=30$ dan banyak koeefisien yang di estimasi $\quad(\mathrm{k})=$ 2 , didapat nilai $\mathrm{du}=1,77$ dan nilai $4-\mathrm{du}$ $=2,23$ jadi nilai Durbin -Watson $(\mathrm{d})$ berada pada diantara nilai du dan 4- du.
Dengan kata lain nilai $\mathrm{du}=1,77<\mathrm{d}=$ $1,628<4-\mathrm{du}=2,23$. Bearti model tersebut tidak ada autokorelasi.

\section{c.Heteroskedastisitas}

Heteroskedastisita diuji menggunakan metode Glesyer dengan cara membuat regresi antara absolut residual sebagai variabel terikat dengan setiap variabel bebas. Jika masing masing variabel bebas tidak berpengaruh secara signifikan terhadap absolut residual maka dalam model regresi tidak terjadi gejala heteroskedastisitas. Hasil uji terlihat pada tabel berikut :

\section{Tabel 4.11}

\begin{tabular}{|c|c|c|c|c|}
\hline $\begin{array}{c}\text { Variabel } \\
\text { bebas }\end{array}$ & $\begin{array}{c}\text { Koeff- } \\
\text { Regresi }\end{array}$ & $\mathrm{T}$ & Sig & Keputusan \\
\hline X1 & 0,04378 & 0,505 & 0,535 & Tidak \\
X2 & 0,01247 & 0,233 & 0,713 & $\begin{array}{c}\text { Signifikan } \\
\text { Tidak } \\
\text { Signifikan }\end{array}$ \\
\hline \multicolumn{3}{|l|}{ Variabel terikat = Absolut Residual } \\
\hline
\end{tabular}

Hasil perhitungan regresi nilai signifikansi masing-masing variabel > 0,05 menunjukkan bahwa nilai residual konstan, sehingga asumsi homokedastisitas terpenuhi atau tidak adanya heteroskedstisitas dalam modal regresi.

\subsection{Hasil Uji Model}

Berdasarkan model yang telah dibangun didepan maka untuk menguji hipotesis 1 menggunakan SPSS 19 for Window, sebelum dilakukan analisa lebih jauh terhadap pengembangan Karir ( $\mathrm{Y}$ ) yang merupakan instrumen yang akan dianalisis maka terlebih dahulu akan disajikan hasil -hasil regresi Performance . Hasil pengujian dapat terlihat pada tabel 4.12 berikut: 


\begin{tabular}{|l|c|c|c|}
\hline \multicolumn{1}{|c|}{ Variabel } & $\begin{array}{c}\text { Koeffisien } \\
\text { Regresi }\end{array}$ & t.Hitung & Sig.t \\
\hline \multicolumn{1}{|c|}{ Pelatihan dan } & 0,761 & 4,871 & 0,000 \\
$\begin{array}{c}\text { Pengembangan( } \\
\text { X1) }\end{array}$ & 0,815 & 3,496 & 0,001 \\
Prestasi Kerja ( & & & \\
X2) & & & \\
\hline Konstanta & 4,592 & & \\
F Hitung & 11.264 & & \\
Sig F & 0,000 & & \\
R & 0,711 & & \\
$\mathrm{R}^{2}$ & 0,506 & & \\
\hline
\end{tabular}

Tabel 4.12

Dependent Variabel pengembangan Karier, Sumber: Data diolah

Sehingga model yang dibentuk dari persamaan hasil proses perhitungan regresi tersebut diatas adalah: $\mathrm{Y}=4,592+0,761$ $\mathrm{X} 1+0,815 \mathrm{X} 2$

Dari tabel diatas juga di ketahui thitung variabel pelatihan dan Pengembangan 4,871 dan Prestasi kerja 3,496 , Selanjutnya dengan derajat bebas ( $\mathrm{db}$ ) 30 pada taraf kepercayaan $95 \%$ diperoleh $\mathrm{t}$ tabel sebesar 2,048.maka dapat disimpulkan bahwa baik pelatihan dan pengembangan maupun prestasi kerja secara signifikan mempengaruhi pengembangan karier pegawai.

\subsection{Pengujian Hipotesis Penelitian 1 .Uji Serempak}

Untuk menguji hipotesis bahwa faktor Pelatihan dan Pengembangan serta Prestasi Kerja terhadap Pengembangan Karir Pegawai Negeri Sipil di Dinas Koperasi Usaha Mikro Kecil Menengah digunakan Uji serempak ( Uji F ), dengan kriteria uji yang digunakan adalah :

- Jika F hit > F tab, maka Ho di tolak artinya terdapat pengaruh yang signifikan dari variabel bebas ( $\mathrm{Xi}$ ) terhadap variabel terikat ( $\mathrm{Y}$ )

- Jika Fhit < F tab, maka Ho diterima artinya tidak terdapat pengaruh yang signifikan dari variabel bebas ( $\mathrm{Xi}$ ) terhadap variabel terikat ( $\mathrm{Y}$ ).

Dari tabel 4.12 diperoleh nilai $\mathbf{F}$ hitung sebesar 11,264, dengan menggunakan tingkat kepercayaan ( confidence Interval ) $95 \%$ atau $\boldsymbol{\alpha}=0,05 \%$ maka dari tabel distribusi $\mathrm{F}$ diperoleh nilai 3,34 .Dengan membandingkan nilai $\mathbf{F}$ hitung dan $\mathbf{F}$ tabel maka $\mathrm{F}$ hitung $>\mathrm{F}$ tabel, keputusannya adalah H0 di tolak dan $\mathrm{Ha}$ di terima, artinya secara serempak pelatihan dan pengembangan serta prestasi kerja pegawai berpengaruh secara signifikan terhadap pengembangan karir pegawai di Dinas Koperasi Usaha Mikro Kecil Menengah.

\section{Uji Parsial}

Pengujian hipotesis secara parsial dilakukan menurut uji Statistik t $\mathbf{t}$ (uji t t)

Dengan ketentuan menerima Ho jika diproleh $\mathrm{t}$ hitung lebih kecil dari $\mathrm{t}$ tabel pada taraf kepercayaan $95 \%$ atau signifikansi $0,05 \%$, dan sebaliknya menerima Ha jika $\mathrm{t}$ hitung lebih besar dari $\mathrm{t}$ tabel. Pada tabel 4.12 terlihat $\mathrm{t}$ hitung variabel Pelatihan dan Pengembangan $=4,871$, dan Prestasi Kerja $=3,496$

Selanjutnya dengan derajat bebas (db)30 pada taraf kepercayaan $95 \%$ diperoleh $\quad \mathrm{t}$ tabel $=1,697$, maka dapat disimpulkan bahwa baik Pelatihan dan Pengembangan maupun Prestasi Kerja Pegawai secara Signifikan mempengaruhi pengembangan karir Pegawai.

\section{Koefisien Determinasi ( $\mathbf{R}^{2}$ )}

Koefisien Determinasi pada dasarnya mengukur seberapa jauh kemampuan model dalam menerangkan variasi variabel independent.Nilai koefisien determinasi yang kecil berarti kemampuan variabel-variabel independen dalam menjelaskan variasi variabel dependen amat terbatas.Nilai koefisien determinasi yang mendekatisatu berarti variabel variabel independen memberikan hampir semua informasi yang dibutuhkan untuk memprediksi variasi variabel dependen.

Dari tabel 4.12 dapat diketahui kofisien determinasi ( $\mathrm{R}$ square) sebesar 0,506 atau 50,6\%. Hasil tersebut memberikan pengertian bahwa variabel dependen 
yaitu Pengembangan Karir Pegawai dapat dijelaskan oleh variabel Independen yang terdiri dari Pelatihan dan Pengembangan ( X1 ) dan Prestasi Kerja Pegawai (X2)dengan nilai 50,6\%, sedangkan sisanya 49,4\% dijelaskan oleh variabel independen lainnya yang tidak dimasukkan kedalam model penelitian ini.

\subsection{Pembahasan}

Berdasarkan hasil analisis regresi tersebut maka dapat diprediksi bahwa kinerja karyawan akan bertambah atau meningkat secara berarti apabila diberikan pelatihan dan pengembangan karyawan, maka dapat dipastikan Karir karyawan akan lebih baik atau meningkat secara signifikan.Tingkat pendidikan pegawai di Dinas Koperasi Usaha Mikro Kecil Menengah kebanyakan adalah Strata 1 ( S1), hal ini menggambarkan organisasi ini menghargai nilai profesionalisme akan lebih mudah berkembang oleh mereka yang mempunyai jenjang pendidikan lebih tinggi.

Menurut pegawai bagian personalia Dinas Koperasi mempunyai program pelatihan terhadap karyawannya yang teratur dan bergiliran sesuai dengan kebutuhan.misalnya kehadiran teknologi komputer dan penggunaan akses internet mendorong Dinas Koperasi mempersiapkan sesi sesi pelatihan komputer pada pegawainya.Pengetahuan dan keterampilan yang baik disertai dengan pengawasan yang konsisten membuat setiap pegawai terbiasa mawas diri serta berdisiplin.

$$
\text { Berdasarkan hasil }
$$

pengujian hipotesis penelitian dapat diketahui bahwa baik secara serempak maupun secara parsial, kedua variabel penelitian ( pelatihan dan pengembangan serta prestasi kerja) memberikan pengaruh yang signifikan terhadap pengembangan karir pegawai di Dinas Koperasi Usaha Mikro Kecil
Menengah, kedua variabel juga secara simultan memberikan kontribusi $(50,6 \%)$ yang besar terhadap pengembangan karir pegawai. Pelatihan dan pengembangan merupakan kegiatan paket yang umumnya diterapkan bagi pegawai pada instansi pemerintahan, yang ditujukan untuk meningkatkan pengetahuan, keterampilan dan pemantapan sikap bagi para pegawai, sehingga diharapkan dari hasil pelaksanaan perogram tersebut dapat meningkatkan kinerja pegawai secara umum.

\section{V.KESIMPULAN DAN SARAN 5.1.Kesimpulan}

Berdasarkan hasil penelitian dan pembahasan, maka dapat disimpulkan bahwa secara simultan dan parsial pelaksanaan program pelatihan dan pengembangan serta prestasi kerja berpengaruh signifikan positif terhadap pengembangan karir pegawai Dinas Koperasi Usaha Mikro Kecil Menengah. Prestasi Kerja mempunyai pengaruh lebih besar dibandingkan dengan Pelatihan dan Pengembangan terhadap Pengembangan Karir Pegawai.

\subsection{Saran - saran}

Berdasarkan kesimpulan penelitian maka disarankan :

1.Pelaksanaan program pelatihan dan pengembangan kerja pegawai yang telah terlaksana secara baik diharapkan mampu menjadi pendorong untuk peningkatan prestasi kearah yang lebih baik .

2.Besarnya pengaruh yang diberikan oleh program pelatihan dan pengembangan serta prestasi kerja pegawai terhadap peningkatan karir diharapkan menjadi salah satu pertimbangan bagi para pegawai untuk tujuan pengembangan karir para pegawai tersebut. 
3. Faktor pelatihan dan pengembangan karyawan merupakan faktor yang tidak boleh diabaikan dalamaktivitas organisasi saat ini. Oleh karena itu hendaknya pemberian program pelatihan dan pengembangan bagi karyawanperlu dipertahankan bahkan lebih ditingkatkan agar kinerja yang telah ada dapat dipertahankan ataupun lebih ditingkatkan.

4. Hendaknya instansi pemerintahan harus memperhatikan tujuan, komponen, materi maupun metode dari pelatihan dan pengembangan agar prestasi kerja karyawan akan tetap terjaga dengan baik dan bahkan lebih ditingkatkan sehingga karyawan akan merasa dihargai serta kebutuhan mereka dapat segera terpenuhi.

5. Untuk lebih memaksimalkan performance kerja karyawan, maka pemberian pelatihan dan pengembangan sebaiknya disesuaikan dengan tujuan organisasi.

Daftar Pustaka

Alwi Syafaruddin ( 2001), Manajemen Sumber Daya Manusia, Strategi Keunggulan Kompetitif, Balai Penerbitan Fakultas Ekonomi, Yogyakarta

\section{Arikunto Suharsini ( 2002 ), Prosedur Penelitian Suatu Pendekatan Praktek, Edisi revisi V. PT Rineka Cipta, Jakarta}

Dessler Garry ( 2006), MSDM Jilid II, PT.Indeks jakarta

Gomes, Faustino Cardoso ( 2003), Manajemen Sumber Daya Manusia, Andi Jogyakarta

Hasibuan Malayu ( 2012 ), Organisasi dan
MotivasiPeningkatan Produktivitas, PT.Bumi Aksara Jakarta

Mangku Prawira

Syafri,2002,Manajemen

Sumber\ Daya manusia,Penerbit Ghalia Indonesia,Jakarta

Sulistiyani,Ambar Teguh dan Rosidah,2003, Manajemen Sumberdaya manusia konsep teori Pengembangan dalam konteks Organisasi Publik, Graha ilmu Jakarta.

Kepegawaian, Kanisius, Yogyakarta

Moreehead\& Griffin ( 2000), Managing People and Organization, Organizational Behavior,Houghton Miffin Compny,USA

Sutarto , Herry SE Phd .dkk (2012) , Strategic Management, “ Pengembangan Karyawan”, Asosiasi Institut Manajemen Indonesia, Jakarta

Simamora Henry ( 2004), Manajemen Sumber daya Manusia , STIE YPKN, Yogyakarta

Pramudyo Chrisogonus ( 2007), Cara Pintar jadi Trainer, Percetakan Galang Press Jakarta

Rivai, Veithzal ( 2010 ) , Manajemen Sumber Daya Manusia untuk Perusahaan: dari Teori ke Praktek, Raja Grafindo Persada, Jakarta

Weightman Jane,( 2002), Managing Human Resourses “ Individual Orientation to work"Jaico Publishing House,London, UK 
Kaplan Roberts dan Norton david ( 2004), Strategy Maps, “ Converting Intangible Assets into Tangible Outcomes " Harvard Business School Publishing Corporation, Boston USA 